JURNAL SPORTA SAINTIKA

P-ISSN 2505-5651

E-ISSN 2579-5910

\title{
PEMBELAJARAN PASSING SEPAK BOLA MELALUI TIPE STUDENT TIM ACHIEVENMENT DIVISION (STAD)
}

\author{
Turiyem ${ }^{1}$, Ghoirumamnun Limayyasya ${ }^{2}$ \\ ${ }^{12}$ SD Negeri 03 Belungai Dalam, Kecamatan Toba, Kabupaten Sanggau, Provinsi \\ Kalimantan Barat, Indonesia \\ turiyemsdn03@gmail.com¹, ghoirumamnunlimayyasya@gmail.com²
}

\begin{abstract}
The purpose of this study was to determine the Football Passing Learning through Student Type Achievenment Division Team at SDN 03 Belungai Dalam. The research method used is classroom action research, namely research which is a follow-up to descriptive research. The subjects in this study were 24 students of grade V SDN 03 Belungai Dalam. Based on the results of research at SDN 03 Belungai Dalam especially in class V, it can be concluded that learning using the Student Teams Achievement Division (STAD) type learning model in Physical Education lessons, the passing material of class $\mathrm{V}$ football games increases. with a value of 70.17 in the pre-cycle, then 74.62 in cycle 1 , and increased to 80.38 in cycle 2 . Of the entire cycle that has been done, it has a positive impact on learning.
\end{abstract}

Keywords: Passing, Football

\begin{abstract}
Abstrak
Tujuan penelitian ini adalah Untuk mengetahui pembelajaran passing sepak bola melalui tipe Student Tim Achievenment Division di SDN 03 Belungai Dalam. Metode penelitian yang dilakukan ini adalah penelitian tindakan kelas yaitu penelitian yang merupakan tindak lanjut dari penelitian deskriptif. Adapun subyek dalam pembelajaran ini adalah siswa kelas V SDN 03 Belungai Dalam sebanyak 24 siswa. Berdasarkan hasil penelitian di SDN 03 Belungai Dalam khususnya kelas $\mathrm{V}$, dapat disimpulkan bahwa pembelajaran menggunakan model pembelajaran tipe Student Teams Achievement Division (STAD) pada pelajaran Penjas materi passing permainan sepak bola kelas $\mathrm{V}$ meningkat. dengan nilai 70.17 pada pra siklus, kemudian 74.62 pada siklus 1, dan meningkat menjadi 80.38 pada siklus 2. Dari keseluruhan siklus yang sudah di lakukan memberikan dampak posistif pada sebuah pembelajaran.
\end{abstract}

Kata kunci: Passing, Sepak Bola

\section{PENDAHULUAN}

Pembelajaran merupakan kegiatan guru secara terprogram dalam desain instruksional untuk membuat siswa belajar secara aktif yang menekankan pada penyediaan sumber belajar. Pembelajaran menjadi satu kesatuan di dalam pendidikan, pembelajaran merupakan suatu proses interaksi antara siswa dan guru atau individu yang satu dengan individu yang lainnya (Afandi, 2013). 
JURNAL SPORTA SAINTIKA

P-ISSN 2505-5651

E-ISSN 2579-5910

Sepak bola pada dasarnya merupakan olahraga yang memainkan bola dengan menggunakan kaki, permainan sepak bola memiliki tujuan dalam permainannya yaitu untuk mencetak gol sebanyak banyaknya dengan ketentuan dan peraturan yang telah ditetapkan untuk mencapai sebuah kemenangan. Sepak bola sendiri juga memiliki beberapa teknik dasar diantaranya adalah passing (Tarju \& Wahidi, 2017).

Passing merupakan salah satu teknik yang mendasar agar tercapainya suatu permainan sepak bola, passing disebut juga sebagai teknik ataupun cara memindahkan bola dari satu tempat ke tempat yang lain (Harianto et al., 2016). Selain itu passing juga salah satu teknik dasar sepak bola yang dilakukan dengan cara yang tidak begitu mudah dan sulit bergantung bagaimana kemampuan keterampilan seseorang dalam menguasai teknik dasar tersebut (Ardianta \& Hariadi, 2017).

Berdasarkan pengamatan dan komunikasi awal dengan pengajar ditemukan beberapa masalah. Pertama, sebagian besar peserta didik belum mengetahui teknik dasar yang benar dalam permainan sepak bola. Oleh karena itu, diperlukan persiapan yang matang untuk mendukung kegiatan pembelajaran sepak bola agar sesuai dengan tujuan awal yaitu dapat meningkatkan kemampuan dari masing-masing peserta didik. Kedua, perkenaan bola yang dilakukan oleh peserta didik pada saat melakukan passing tidak tepat yang berakibatkan arah bola tidak mengarah tepat sasaran. Ketiga, peneliti juga menemukan beberapa hal yang menjadi kendala dalam pengaplikasian teknik passing yaitu peserta didik cenderung pasif dan bermalas-malasan dalam kegiatan pembelajaran sehingga kegiatan pembelajaran hanya satu arah. Berdasarkan penjelasan tersebut dapat disimpulkan bahwa peneliti memiliki tingkat kepentingan yang tinggi untuk mengatasi permasalahan yang terjadi di SDN 03 Belungai Dalam berkaitan dengan hasil belajar passing peserta didik.

Peneliti dalam hal ini menawarkan solusi berupa penerapan model Cooperative Learning Tipe Student Teams Achievement Division dalam materi sepak bola secara khusus pada aspek hasil belajar passing. Penggunaan model Cooperative Learning Tipe Student Teams Achievement Division diharapkan mampu mengatasi kesulitan yang selama ini dialami oleh peserta didik (Muharom, 2014). Penggunaan model yang bervariasi ini juga diharapkan dapat menarik perhatian peserta didik untuk mengikuti pembelajaran secara efektif dan efisien (Esminarto et al., 2016).

Banyak model pembelajaran yang ditawarkan untuk dapat meningkatkan kemampuan siswa, salah satunya yaitu pembelajaran kooperatif (Zainal\&Taufiq, 2014). Pembelajaran kooperatif merupakan model pembelajaran yang paling mudah digunakan pada guru yang masih pemula dan juga melibatkan semua siswa, karena saat pembelajaran sportasaintika.ppj.unp.ac.id 
JURNAL SPORTA SAINTIKA

P-ISSN 2505-5651

E-ISSN 2579-5910

berlangsung siswa dapat bekerja sama antara siswa yang sudah bisa maupun yang belum bisa (Arimbawa et al., 2017). Oleh karena itu, peneliti akan menggunakan metode pembelajaran kooperatif dalam penelitian. Manfaat lainnya dalam model ini adalah siswa juga dapat berperan aktif baik siswa yang sudah bisa maupun yang belum bisa (Permadi \& Syam, 2016). Semua siswa dapat ikut terlibat dalam pembelajaran passing sepak bola. Model pembelajaran kooperatif tipe Student Teams Achievement Division (STAD) menjadi pilihan peneliti untuk meningkatkan kemampuan dalam materi passing. Oleh karena itu, peneliti akan menggunakan kelompok agar materi yang diajarkan dapat tersampaikan dengan baik dan siswa yang kurang aktif dapat mengikuti proses pembelajaran serta memperoleh nilai di atas KKM. Melalui model pembelajaran ini, diharapkan ada peningkatan kemampuan siswa dalam materi passing dalam sepakbola.

Model Cooperative Learning menurut (Slavin, 2010) adalah bentuk pembelajaran dengan cara peserta didik belajar dan bekerja dalam kelompok-kelompok kecil secara kolaboratif yang anggotanya terdiri dari empat sampai enam orang dengan struktur kelompok yang bersifat heterogen menurut tingkat prestasi, jenis kelamin. Pembelajaran Cooperative Learning menuntut guru untuk dapat mengelola kelas dengan efektif pada saat menyampaikan materi sesuai dengan prinsip dasar sistem pembelajaran Cooperative Learning tersebut (Khan \& Inamullah, 2011). Selain itu dalam pembelajaran Cooperative Learning peserta didik dapat saling belajar bersama dan pembelajaran tidak hanya dari seorang guru langsung kepada peserta didik saja (Yuliani, 2019). Model Cooperative Learning memiliki beberapa tipe, diantaranya tipe Student Teams Achievement Division (Yudhianto \& Hartati, 2013). Menurut (Sharan et al., 2013) mengatakan bahwa gagasan utama di belakang STAD adalah memacu peserta didik untuk saling mendorong dan membantu satu sama lain untuk menguasai keterampilan yang diajarkan guru. Berdasarkan penjabaran tersebut, dapat disimpulkan bahwa peneliti tertarik mengadakan penelitian tentang "Pembelajaran Passing Sepak Bola Melalui Tipe Student Tim Achievenment Division di SDN 03 Belungai Dalam Kecamatan Toba Kabupaten Sanggau".

\section{METODELOGI PENELITIAN}

Penelitian ini dilakukan pada SDN 03 Belungai Dalam Kecamatan Toba Kabupaten Sanggau. Subyek dalam penelitian ini adalah siswa kelas V SDN 03 Belungai Dalam dengan jumlah seluruhnya adalah 24 siswa.

Metode yang akan digunakan dalam penelitian ini adalah metode deskriptif kualitatif. (Mukhtar, 2013) menyatakan bahwa metode deskriptif adalah suatu penelitian yang diupayakan untuk mengamati permasalahan secara sistematis dan akurat mengenai fakta 
JURNAL SPORTA SAINTIKA

P-ISSN 2505-5651

E-ISSN 2579-5910

dan sifat objek tertentu. Penelitian deskriptif merupakan penelitian yang dimaksudkan untuk mengumpulkan informasi mengenai status suatu gejala yang ada, yaitu keadaan gejala menurut apa adanya pada saat penelitian dilakukan tanpa bermaksud membuat kesimpulan yang berlaku untuk umum atau generalisasi (Sugiyono, 2012).

Bentuk penelitian yang digunakan adalah penelitan tindakan kelas (PTK). Penelitian tindakan kelas merupakan suatu pencermatan terhadap kegiatan belajar berupa sebuah tindakan yang sengaja dimunculkan dan terjadi dalam sebuah kelas secara bersama. Secara umum menurut (Arikunto, 2010b) prosedur atau langkah-langkah penelitian tindakan kelas dapat dilihat ataupun digambarkan sebagai berikut:

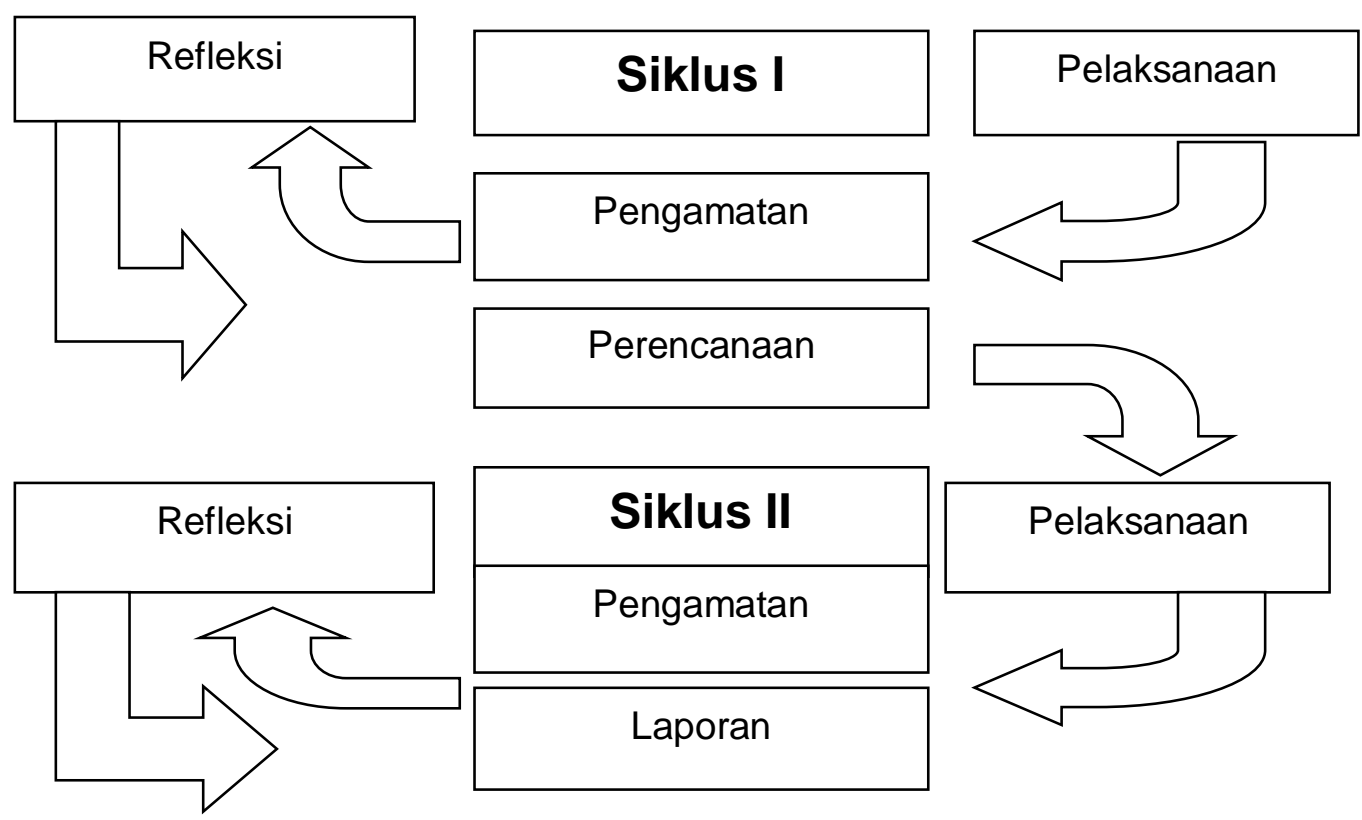

Gambar 1. Model Siklus Penelitian Tindakan Kelas (Arikunto, 2010)

Teknik pengumpulan data dalam penelitian ini yaitu teknik observasi, teknik pengumpulan data melalui pencermatan dokumen atau dokumentasi, dan teknik pengumpulan data melalui lembar tes. (Sugiyono, 2010) menyatakan bahwa teknik pengumpulan data merupakan langkah yang paling utama dalam penelitian, karena tujuan utama dari penelitian adalah mendapatkan data. Tanpa mengetahui teknik pengumpulan data, maka peneliti tidak akan mendapatkan data yang memenuhi standar data yang ditetapkan (Ali Maksum, 2012).

Untuk menganalisis data sub masalah 1,2, dan 3 yang berkaitan dengan mendeskripsikan hasil rata-rata kemampuan guru untuk merencanakan pembelajaran, melaksanakan pembelajaran, dan hasil belajar peserta didik maka dikemukakan rumus rata- 
JURNAL SPORTA SAINTIKA

P-ISSN 2505-5651

E-ISSN 2579-5910

rata sebagai berikut:

$M=\frac{\sum X}{\mathrm{n}}$

Keterangan sebagai berikut:

$\mathrm{M} \quad=$ Mean yang dicari

$\sum \mathrm{X}=$ jumlah seluruh skor

$\mathrm{N} \quad$ = banyaknya skor

Untuk menentukan kategori dipergunakan tolak ukur sebagai berikut:

Tabel 1. Tolak Ukur Penilaian

\begin{tabular}{|c|c|c|}
\hline Interval Nilai & Predikat & Keterangan \\
\hline $90-100$ & A & Sangat Baik \\
\hline $80-89$ & B & Baik \\
\hline $75-79$ & C & Cukup \\
\hline$<75$ & D & Kurang \\
\hline
\end{tabular}

\section{HASIL PENELITIAN}

\section{Hasil Pra Siklus}

Pada tahap pra siklus yang telah di laksanakan di SDN 03 Belungai Dalam, terdapat tingkat ketuntasan pada tabel berikut ini:

Tabel 2. Hasil Belajar Peserta Didik Pra Siklus

\begin{tabular}{|c|c|c|c|}
\hline Interval Nilai & $\begin{array}{c}\text { Banyaknya } \\
\text { Peserta didik }\end{array}$ & Presentase & Keterangan \\
\hline $76-100$ & 6 & $25 \%$ & TUNTAS \\
\hline$<76$ & 18 & $75 \%$ & BELUM TUNTAS \\
\hline Jumlah & 24 & $100 \%$ & \\
\hline
\end{tabular}


JURNAL SPORTA SAINTIKA

P-ISSN 2505-5651

E-ISSN 2579-5910

Diagram 1 Hasil Belajar Peserta Didik Pra Siklus

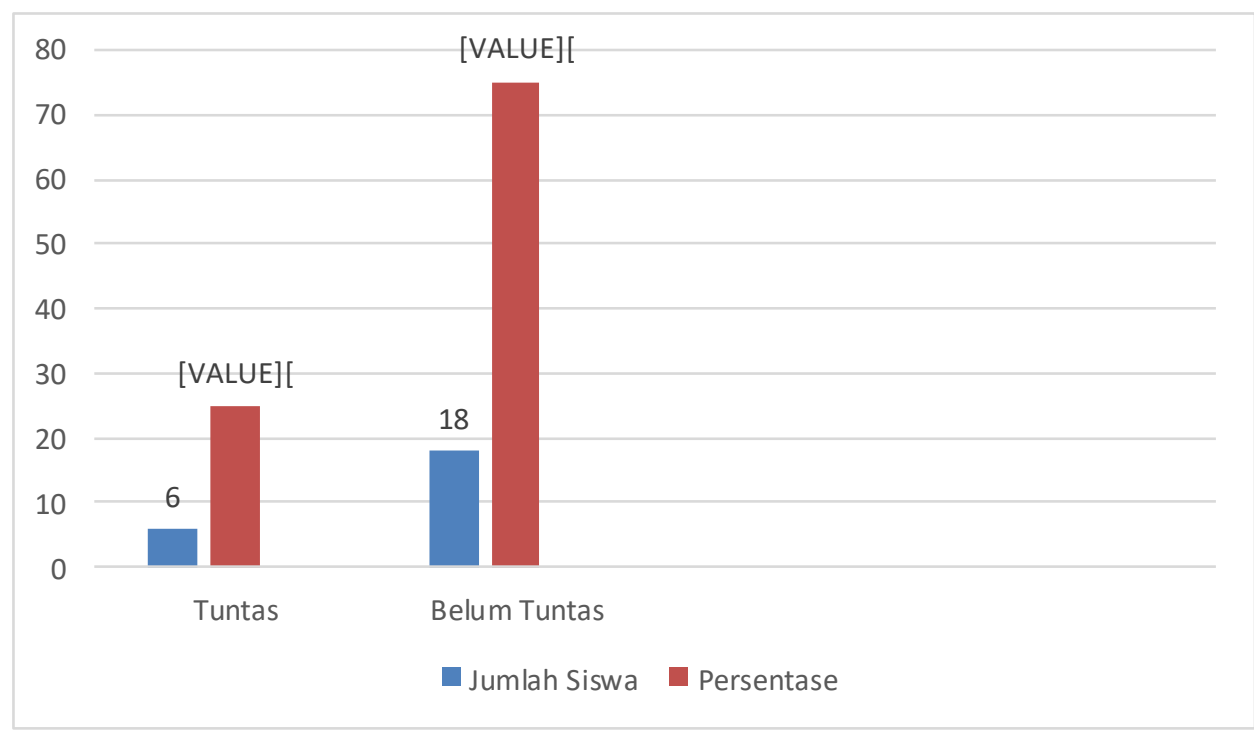

Adapun hasil yang telah di peroleh pada saat melakukan pra siklus dengan ketuntasan 76 sesuai KKM terdapat 18 siswa yang tidak tuntas dan 6 siswa yang tuntas, nilai rata-rata yang di peroleh pada pra siklus ini adalah 70.17 dan hanya memiliki presentase ketuntasan $25 \%$.

Berdasarkan hasil di atas terdapat beberapa hal yang harus di lanjutkan pada siklus 1 diantaranya adalah hanya terdapat $25 \%$ siswa yang telah mengalami ketuntasan dan dengan nilai rata-rata 70.17 , dengan hasil demikian siswa masih belum memenuhi kriteria KKM yang telah ditetapkan, untuk itu dilanjutkan dengan siklus 1.

\section{Hasil Pelaksanaan Siklus 1}

\section{a. Perencanaan}

Pada tahap rencana, peneliti mengadakan pertemuan dan bekerja sama dengan guru kolaborator untuk menentukan bagaimana berlangsungnya proses penelitian. Adapun yang dilakukan peneliti dalam tahap rencana adalah:

1) Membuat RPP (Rencana Pelaksanaan Pembelajaran) untuk melaksanakan penelitian siklus 1 serta menentukan materi yang akan disampaikan

2) Menentukan media, sumber belajar, dan metode pembelajaran yang akan digunakan. Metode pembelajaran yang akan diterapkan, yaitu model pembelajaran tipe student teams achievement division dengan materi passing sepak bola.

3) Menyiapkan lembar instrumen. 
P-ISSN 2505-5651

E-ISSN 2579-5910

\section{b. Pelaksanaan}

Pelaksanaan siklus 1 dilakukan pada Rabu 12 Februari 2020, pukul 06.45 sampai 09.00 WIB di SDN 03 Belungai Dalam. Pada kegiatan pendahuluan ini dimulai dengan literasi selama 15 menit kemudian pada pukul 07.00 pembelajaran sudah siap dilaksanakan. Setelah itu mengkoordinasikan kelas agar siswa siap mengikuti pembelajaran, berdoa, mengecek kehadiran siswa, memberikan apersepsi, menyampaikan tujuan pembelajaran, dan menginformasikan kegiatan pembelajaran yang akan dilakukan.

Kegiatan inti pembelajaran dimulai dengan guru menjelaskan aspek penilaian yang akan digunakan pada kegiatan inti, adapun aspek yang akan digunakan adalah aspek kognitif, aspek afektif dan aspek psikomotor. Kemudian di lanjutkan dengan membagi kelompok-kelompok kecil yang terdiri dari 4-5 siswa, Selanjutnya siswa menyimak penjelasan guru mengenai materi passing permainan sepak bola. Setelah itu setiap kelompok diminta untuk berdiskusi mengenai materi passing. Kemudian guru megambil beberapa undian secara acak dan nomor atau kelompok yang terpilih diminta untuk maju ke depan untuk membacakan hasil diskusi mereka, setelah itu kelompok yang terpilih tadi kembali ke posisi semula dan di lanjutkan dengan kelompok terpilih yang lainnya. Setelah kelompok yang terpilih maju kemudian setiap kelompok melakukan teknik dasar passing yang di lakukan secara berkelompok. Kemudian guru meminta untuk berdiskusi mengenai materi passing permainan sepak bola.

Setelah melakukan kegiatan di atas, guru memotivasi dan mendorong kreativitas dalam bentuk bertanya dan memberi gagasan yang menarik dan menantang siswa untuk didalami. Kemudian guru meminta beberapa siswa atau kelompok untuk ditanya mengenai passing permainan sepak bola. Selanjutnya adalah melakukan proses tanya 
JURNAL SPORTA SAINTIKA

P-ISSN 2505-5651

E-ISSN 2579-5910

jawab dan menjelaskan materi yang belum dimengerti oleh siswa dan di lanjutkan dengan membimbing siswa untuk menggali informasi mengenai passing permainan sepak bola.

Pada kegiatan akhir, siswa bersama guru merangkum dan menyimpulkan materi pembelajaran, kemudian memberikan tes pada aspek kognitif untuk melihat hasil belajar siswa dan diakhiri dengan doa dan salam.

\section{c. Observasi}

Pada tahap observasi dilakukan oleh kolaborator saat pembelajaran berlangsung. Ibu Halimah, S.Pd berperan sebagai observer atau yang mengamati proses pembelajaran dari awal sampai akhir. Adapun hasil pengamatan pada siklus 1 adalah sebagai berikut:

Pada siklus 1 diperoleh nilai rata-rata hasil belajar peserta didik pada materi passing permainan sepak bola. Data hasil belajar dapat dilihat pada tabel berikut:

Tabel 3. Hasil Belajar Peserta Didik Siklus 1

\begin{tabular}{|c|c|c|c|}
\hline Interval Nilai & $\begin{array}{c}\text { Banyaknya } \\
\text { Peserta didik }\end{array}$ & Presentase & Keterangan \\
\hline $76-100$ & 11 & $45.83 \%$ & TUNTAS \\
\hline$<76$ & 13 & $54.17 \%$ & BELUM TUNTAS \\
\hline Jumlah & 24 & $100 \%$ & \\
\hline
\end{tabular}

\section{Diagram 2 Hasil Belajar Peserta Didik Siklus 1}

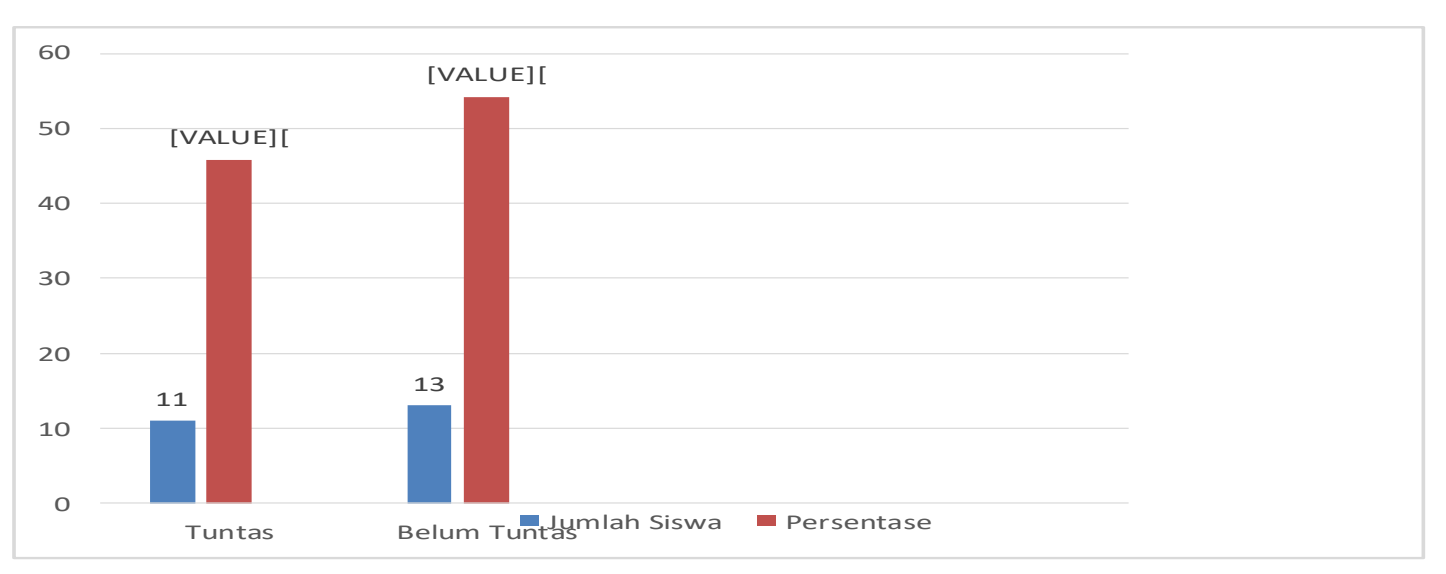


P-ISSN 2505-5651

E-ISSN 2579-5910

Pada pengamatan terhadap hasil belajar di siklus 1 terdapat 13 orang peserta didik yang belum mencapai nilai ketuntasan karena mendapat nilai di bawah 76 dan 11 orang peserta didik lainnya dinyatakan tuntas setelah mendapat nilai di atas 76, adapun nilai ketuntasan dalam pelajaran Penjas sesuai KKM yang ada di sekolah adalah 76 .

Pada pra siklus diperoleh nilai rata-rata hasil belajar peserta didik yaitu 70.17 dan memiliki nilai presentase ketuntasan $25 \%$ dan pada siklus 1 diperoleh nilai rata-rata hasil belajar peserta didik yaitu 74.62 dan memiliki nilai presentase ketuntasan $45.83 \%$. Karena nilai rata-rata hasil belajar siswa yang didapat belum memuaskan dan memenuhi kriteria KKM, maka penelitian dilanjutkan pada siklus 2.

\section{d. Refleksi}

Refleksi yang ada pada siklus 1 dilakukan setelah melakukan tindakan. Kemudian dari data yang telah diperoleh selama observasi, diadakan kesepakatan atau perbincangan dengan kolaborator sebagai bahan perencanaan pembelajaran selanjutnya. Pada siklus 1 terjadi peningkatan hasil belajar yang dilihat dari naiknya nilai rata-rata siswa dari 70.17 menjadi 74.62 dan dengan presentase ketuntasan $25 \%$ menjadi $45.83 \%$. Hal ini memberikan gambaran bahwa model pembelajaran yang digunakan menunjukkan keefektifan. Oleh karena itu, perlu diperhatikan beberapa hal penting yang menjadi pertimbangan dalam pelaksanaan siklus 2 agar memenuhi kriteria penilaian.

Kelebihan dan kekurangan pada pelaksanaan siklus 1 dari refleksi yang dilakukan adalah sebagai berikut:

1) Kelebihan Siklus 1

a) Terlaksana cukup baik dan lancar dari hal persiapan peneliti maupun kolaborator.

b) Melaksanakan pembelajaran sesuai dengan RPP yang telah dibuat.

c) Skor rata-rata siswa kelas $\mathrm{V}$ mengalami kenaikan ini terjadi setelah mendapat skor rata-rata yang awalnya hanya 69.75 menjadi 74.62. 
JURNAL SPORTA SAINTIKA

P-ISSN 2505-5651

E-ISSN 2579-5910

2) Kekurangan Siklus 1

a) Guru hanya menjelaskan materi secara umum.

b) Guru memberikan contoh passing tidak secara detail.

c) Pembagian kelompok memakan waktu sedikit lama

d) Guru hanya memberikan pujian, tidak memberikan reward pada kelompok pemenang.

e) Terdapat 7 orang siswa yang tidak memenuhi kriteria penilaian sehingga mendapat nilai tidak tuntas.

Untuk memperbaiki perencanaan dan pelaksanaan pada siklus 1 dalam upaya meningkatkan hasil belajar siswa, maka peneliti dan kolaborator mengambil keputusan untuk melaksanakan kegiatan tindakan siklus 2 .

\section{Hasil Pelaksanaan Siklus 2}

\section{a. Perencanaan}

Pada tahap rencana, peneliti mengadakan pertemuan dan bekerja sama dengan guru kolaborator untuk menentukan bagaimana berlangsungnya proses penelitian. Adapun yang dilakukan peneliti dalam tahap rencana adalah:

1) Setelah merefleksi siklus 1, pada siklus 2 guru membuat RPP (Rencana Pelaksanaan Pembelajaran) untuk melaksanakan penelitian.

2) Menentukan media, sumber belajar, dan metode pembelajaran yang akan digunakan. Metode pembelajaran yang akan diterapkan, yaitu model pembelajaran tipe student teams achievement division dengan materi passing permainan sepak bola.

3) Sebelum pembelajaran dimulai, siswa diatur sesuai dengan kelompoknya agar mempersingkat waktu pembagian kelompok.

4) Menyiapkan lembar instrumen.

\section{b. Pelaksanaan}

Pelaksanaan siklus 2 dilakukan pada Rabu 19 Februari 2020, pukul 06.45 sampai 09.00 WIB di SDN 03 Belungai Dalam. Pada kegiatan pendahuluan ini dimulai dengan literasi selama 15 menit kemudian pada pukul 07.00 pembelajaran sudah siap dilaksanakan. Kemudian dimulai dengan mengkoordinasikan kelas agar siswa siap 
JURNAL SPORTA SAINTIKA

P-ISSN 2505-5651

E-ISSN 2579-5910

mengikuti pembelajaran, berdoa, mengecek kehadiran siswa, memberikan apersepsi, menyampaikan tujuan pembelajaran, dan menginformasikan kegiatan pembelajaran yang akan dilakukan.

Kegiatan inti pembelajaran pada siklus 2 ini kurang lebih dengan kegiatan pada siklus 1, pertama dimulai dengan guru menjelaskan aspek penilaian yang akan digunakan pada kegiatan inti, adapun aspek yang akan digunakan adalah aspek kognitif, aspek afektif dan aspek psikomotor. Kemudian guru menyuruh siswa kembali sesuai kelompok yang telah dilaksanakan pada siklus 1 , selanjutnya siswa menyimak penjelasan guru mengenai materi passing permainan sepak bola. Setelah itu setiap kelompok diminta untuk berdiskusi mengenai materi passing dan guru megambil beberapa undian secara acak dan nomor atau kelompok yang terpilih diminta untuk maju ke depan untuk membacakan hasil diskusi mereka, setelah itu kelompok yang terpilih tadi kembali ke posisi semula dan di lanjutkan dengan kelompok terpilih yang lainnya. Setelah kelompok yang terpilih maju kemudian setiap kelompok melakukan passing sesuai dengan teknik dasar yang di lakukan secara berkelompok. Kemudian guru meminta untuk berdiskusi mengenai materi passing permainan sepak bola.

Pada akhir pembelajaran siswa ditanya apakah ada materi yang belum dipahami, bila ada maka guru akan menjelaskan materi itu. Siswa diberi soal untuk mendapatkan hasil belajar. Pembelajaran diakhiri dengan doa dan salam.

\section{c. Observasi}

Pada tahap observasi dilakukan oleh kolaborator saat pembelajaran berlangsung. Ibu Dra. Suhita Budiarti berperan sebagai observer atau yang mengamati proses pembelajaran dari awal sampai akhir. Adapun hasil pengamatan pada siklus 2 adalah sebagai berikut: 
JURNAL SPORTA SAINTIKA

P-ISSN 2505-5651

E-ISSN 2579-5910

Tabel 4 Hasil Belajar Peserta Didik Siklus 2

\begin{tabular}{|c|c|c|c|}
\hline Interval Nilai & $\begin{array}{c}\text { Banyaknya } \\
\text { Peserta didik }\end{array}$ & Presentase & Keterangan \\
\hline $76-100$ & 20 & $83.33 \%$ & TUNTAS \\
\hline$<76$ & 4 & $16.67 \%$ & BELUM TUNTAS \\
\hline
\end{tabular}

Diagram 3 Hasil Belajar Peserta Didik Siklus 2

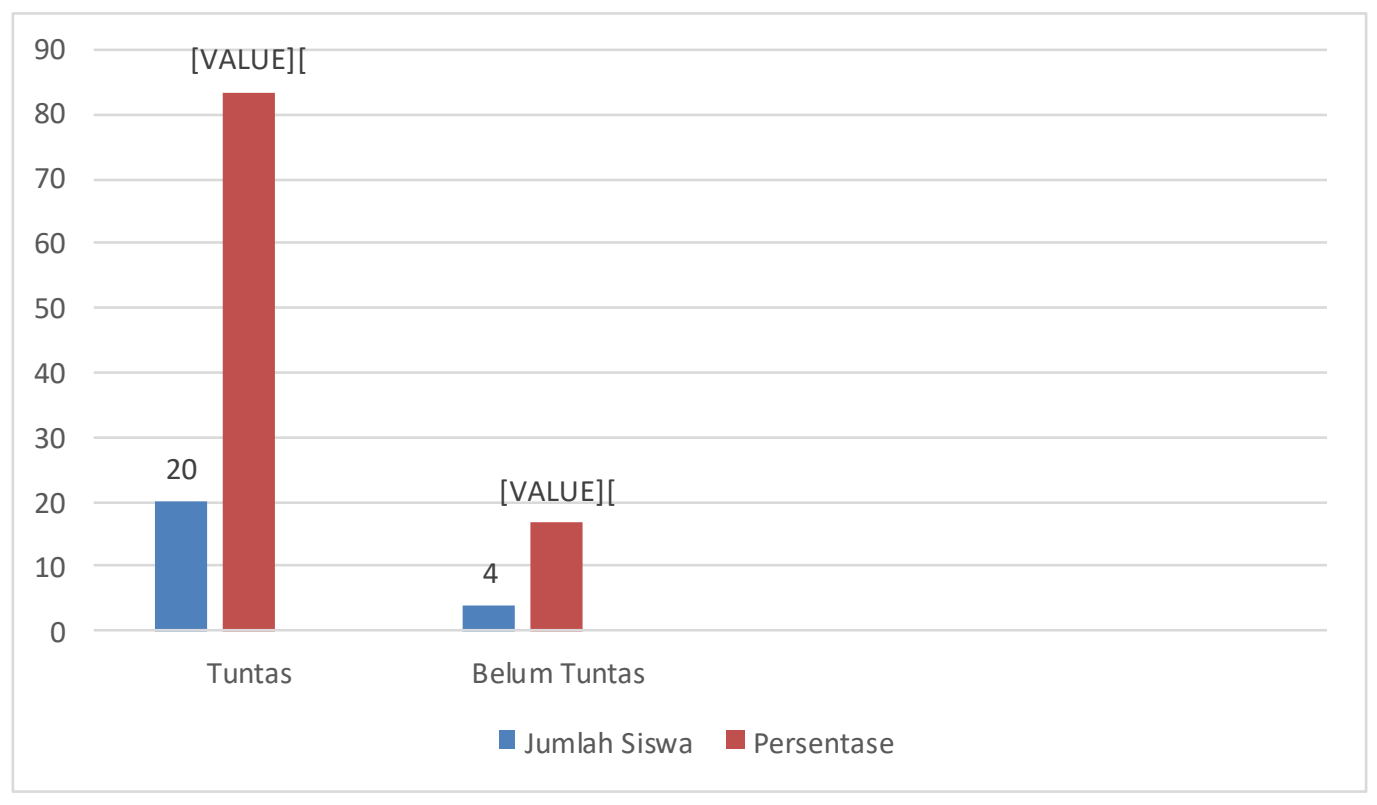

Pada pengamatan terhadap hasil belajar di siklus 2 terdapat 4 orang peserta didik yang belum mencapai nilai ketuntasan karena mendapat nilai di bawah 76 dan 20 orang peserta didik lainnya dinyatakan tuntas setelah mendapat nilai di atas 76, adapun nilai ketuntasan dalam pelajaran Penjas sesuai KKM yang ada di sekolah adalah 76 .

Pada siklus 2 diperoleh nilai rata-rata hasil belajar peserta didik yaitu 80.38 dan memiliki nilai presentase $83.33 \%$ yang meningkat dari nilai pada siklus 1 . Nilai rata-rata pada siklus 2 sudah mencapai titik jenuh karena sudah lebih dari $80 \%$ peserta didik dinyatakan tuntas. Untuk itu peneliti dan kolaborator sepakat untuk mengentikan penelitian. 
JURNAL SPORTA SAINTIKA

P-ISSN 2505-5651

E-ISSN 2579-5910

\section{d. Refleksi}

Refleksi pada siklus 2 dilakukan setelah melakukan tindakan. Dari data yang diperoleh selama observasi, diadakan kesepakatan atau perbincangan dengan kolaborator sebagai bahan perencanaan pembelajaran. Pada siklus 2 terjadi peningkatan hasil belajar yang dilihat dari naiknya niai rata-rata siswa pada siklus 1 yaitu 74.62 dengan presentase $45.83 \%$ meningkat menjadi 80.38 dengan presentase $83,33 \%$. Hal ini memberikan gambaran bahwa model pembelajaran yang digunakan menunjukkan keefektifan.

Adapun kelebihan dan kekurangan pada pelaksanaan siklus 2 dari refleksi yang dilakukan adalah sebagai berikut:

1) Kelebihan Siklus 2

a) Terlaksana cukup baik dan lancar dari hal persiapan peneliti maupun kolaborator.

b) Melaksanakan pembelajaran sesuai dengan RPP yang telah dibuat dan menguasai langkah pembelajaran.

c) Dalam proses pembelajaran, siswa berpartisipasi baik dan antusias dalam mengikuti pelajaran.

d) Siswa mengalami perkembangan yang baik dibandingkan siklus 1 .

e) Skor rata-rata siswa kelas $V$ mengalami kenaikan menjadi 80.38

2) Kekurangan Siklus 2

a) Guru kurang melibatkan siswa dalam penggunaan media.

b) Kurang efektif dalam penggunaan media di lapangan.

Setelah melaksanakan siklus 2 , terjadi peningkatan terhadap skor rata-rata hasil belajar siswa. Kesepakatan antara kolaborator dan peneliti adalah sebanyak $80 \%$ siswa harus tuntas agar hasil pembelajaran dinyatakan tuntas. Untuk itu peneliti dan guru kolaborator sepakat menghentikan penelitian.

\section{PEMBAHASAN}

Setelah melakukan dua siklus penelitian pada pembelajaran Penjas kelas V SDN 03 Belungai Dalam dengan menggunakan tipe Student Teams Achievement Division (STAD) diperoleh hasil akhir skor rata-rata hasil belajar peserta didik. Berikut ini adalah rekapitulasi 
JURNAL SPORTA SAINTIKA

P-ISSN 2505-5651

E-ISSN 2579-5910

data peningkatan skor rata-rata hasil belajar peserta didik setelah menggunakan tipe Student Teams Achievement Division (STAD) pada pembelajaran Penjas materi passing permainan sepak bola kelas $\mathrm{V}$, dapat dilihat pada tabel berikut:

\section{Tabel 5 Hasil Belajar Peserta Didik Pra Siklus, Siklus 1 dan Siklus 2}

\begin{tabular}{|c|c|c|c|}
\hline & $\begin{array}{c}\text { Nilai Pra } \\
\text { Siklus }\end{array}$ & $\begin{array}{c}\text { Nilai } \\
\text { Siklus I }\end{array}$ & $\begin{array}{c}\text { Nilai } \\
\text { Siklus II }\end{array}$ \\
\hline JUMLAH TOTAL & 1684 & 1791 & 1929 \\
\hline RATA - RATA & 70.17 & 74.62 & 80.38 \\
\hline
\end{tabular}

Berdasarkan gafik di atas, tergambar hasil akhir berupa nilai rata-rata peserta didik setelah menggunakan Tipe Student Teams Achievement Division terhadap hasil belajar Passing Permainan Sepak Bola di Kelas V SDN 03 Belungai Dalam. Pada pra siklus dengan nilai rata-rata 70.17, kemudian siklus 1 dengan nilai rata-rata 74.62 dan pada siklus 2 meningkat menjadi 80.38. Meskipun demikian, pada siklus 2 lebih dari $80 \%$ siswa sudah dinyatakan tuntas, sehingga penelitian mencapai titik jenuh dan sepakat untuk menghentikan penelitian.

Jadi pada saat pra siklus memperoleh nilai rata-rata 70.17 dengan presentase $25 \%$, kemudian pada siklus 1 dengan nilai rata-rata 74.62 dengan presentase $45.83 \%$ dan pada siklus 2 meningkat menjadi 80.38 dengan presentase $83.33 \%$ dengan kategori BAIK. Sesuai dengan pendapat Isjoni (2016: 51) tipe STAD "merupakan salah satu tipe kooperatif yang menekankan pada adanya aktivitas dan interaksi diantara siswa untuk saling memotivasi dan saling membantu dalam menguasai materi pelajaran guna mencapai prestasi yang maksimal". Hal ini membuktikan bahwa tipe Student Teams Achievement Division (STAD) dapat meningkatkan hasil belajar peserta didik pada materi passing permainan sepak bola pada pelajaran Penjas kelas IV SDN 03 Belungai Dalam.

\section{KESIMPULAN}

Berdasarkan hasil penelitian di SDN 03 Belungai Dalam khususnya kelas V, dapat disimpulkan bahwa pembelajaran menggunakan model pembelajaran tipe Student Teams Achievement Division (STAD) pada pelajaran Penjas materi passing permainan sepak bola kelas $\mathrm{V}$ meningkat. dengan nilai 70.17 pada pra siklus, kemudian 74.62 pada siklus 1 , dan meningkat menjadi 80.38 pada siklus 2. Dari keseluruhan siklus yang sudah di lakukan memberikan dampak posistif pada sebuah pembelajaran. 
JURNAL SPORTA SAINTIKA

P-ISSN 2505-5651

E-ISSN 2579-5910

\section{DAFTAR PUSTAKA}

Afandi, M. (2013). Model dan Metode Pembelajaran. In Unissula press.

Ali Maksum. (2012). Data, Teknik Pengumpulan Data dan Instrumen Penelitian. Jurnal Cakrawala Kependidikan, 2(8), 107.

Ardianta, \& Hariadi, I. (2017). Pengembangan Model Latihan Passing dan Control pada Atlet Sepak Bola Usia Dini. Indonesia Performance Journal, 1(2), 112-118.

Arikunto, S. (2010a). Dasar-dasar Evaluasi Pendidikan. Jakarta: Bumi Aksara. 2010. In Manajemen Penelitian.

Arikunto, S. (2010b). Prosedur Penelitian Ilmiah. In Rineka cipta, Jakarta.

Arimbawa, I. G. A. A., Astra, I. K. B., \& Satyawan, I. M. (2017). Pengaruh Penerapan Model Pembelajaran Kooperatif Tipe STAD Berbantuan Media Gambar terhadap Hasil Belajar Teknik Dasar Passing Sepak Bola. E-Journal PJKR, 8(2), 1-9.

Esminarto, E., Sukowati, S., Suryowati, N., \& Anam, K. (2016). Implementasi model stad dalam meningkatkan hasil belajar siswa. Briliant: Jurnal Riset Dan Konseptual, 1(1), 16. https://doi.org/10.28926/briliant.v1i1.2

Harianto, 'Gutomo, Nurhadi, M., Wakit, N., \& Sujarwo, E. (2016). Model pembelajaran passing sepak bola di SD. Briliant: Jurnal Riset Dan Konseptual, 1(1), 58. https://doi.org/10.28926/briliant.v1i1.8

Khan, G. N., \& Inamullah, H. M. (2011). Effect of student's team achievement division (STAD) on academic achievement of students. Asian Social Science, 7(12), 211-215. https://doi.org/10.5539/ass.v7n12p211

Muharom, T. (2014). Pengaruh Pembelajaran Dengan Model Kooperatif Tipe Student Teams Achievement Division (Stad) Terhadap Kemampuan Penalaran Dan Komunikasi Matematik Peserta Didik Di SMK Negeri Manonjaya Kabupaten Tasikmalaya. Jurnal Pendidikan Dan Keguruan, 1(1).

Mukhtar. (2013). Metode Praktis Penelitian Deskriptif Kualitatif. In Jakarta: Referensi (GP Press Group.

Permadi, J., \& Syam, A. R. (2016). Penerapan model pembelajaran kooperatif tipe Student Teams Achievement Division (STAD) terhadap hasil belajar dribble bola basket. Jurnal Pendidikan Olahraga Dan Kesehatan, 1(1), 13-23.

Sharan, S., Sharan, Y., \& Geok-Chin Tan, I. (2013). The group investigation approach to cooperative learning. In The International Handbook of Collaborative Learning (pp. 351369). https://doi.org/10.4324/9780203837290-29

Slavin, R. (2010). Model Pembelajaran Kooperatif (Cooperative Learning). April 19, 2010. 
JURNAL SPORTA SAINTIKA

P-ISSN 2505-5651

E-ISSN 2579-5910

Sugiyono. (2010). Metode Penelitian Bisnis. Pendekatan Kuantitatif, kualitatif dan R \& D. Bandung: Alfabeta.

Sugiyono. (2012). Metode Penelitian Kuantitatif, Kualitatif dan R \& D.Bandung:Alfabeta. Metode Penelitian Kuantitatif, Kualitatif Dan $R$ \& D.Bandung:Alfabeta. https://doi.org/10.1017/CBO9781107415324.004

Tarju, T., \& Wahidi, R. (2017). Pengaruh Metode Latihan Terhadap Peningkatan Passing Dalam Permainan Sepak Bola. JUARA: Jurnal Olahraga, 2(2), 66. https://doi.org/10.33222/juara.v2i2.35

Yudhianto, A., \& Hartati, S. christina yuli. (2013). Pengaruh model pembelajaran kooperatif tipe Student Teams Achievement Division (STAD) terhadap hasil belajar servis bawah bolavoli. Jurnal Pendidikan Olahraga Dan Kesehatan, 1(2), 307-310.

Yuliani, N. (2019). The Role of Student Teams Achievement Divisions (STAD) in Improving Student's Learning Outcomes. Classroom Action Research Journal, 3(1), 8-15. https://doi.org/10.17977/um013v3i12019p008

Zainal\&Taufiq. (2014). Penerapan Model Pembelajaran Stad (Student Teams-Achievement Division) Terhadap Hasil Belajar Ketepatan Service Bawah Bolavoli. Jurnal Pendidikan Jasmani, 1(1), 41-44. 